\title{
ANNUAL REPORT OF THE CHIEF MEDICAL OFFICER OF THE MINISTRY OF HEALTH FOR THE YEAR I937.
}

\section{Section on Veneral Diseases}

No striking changes occurred in the working of the Venereal Diseases Scheme in I937, but the year may eventually prove to be noteworthy in the treatment of gonorrhœa by the use of sulphonamide compounds.

\section{Treatment Centres.}

The number of treatment centres in England and Wales at the close of 1937 was I86, including II 8 conducted in voluntary hospitals. The centre at Newcastle-upon-Tyne was transferred from the Royal Victoria Infirmary to specially designed premises at the Newcastle General Hospital ; the new director is a medical officer of the municipal health service. At Bridgwater the centre was transferred to the Health Clinic.

Plans of proposed new premises and alterations of existing centres have been discussed with a number of Local Authorities.

\section{The Incidence of Venereal Diseases in England AND WALES}

Syphilis.-In the Report of the Chief Medical Officer for I936 evidence was afforded to show that the treatment centres deal with more than 85 per cent. of the fresh infections coming under medical care in this country. Nothing has since occurred to alter this estimate. The returns from the treatment centres showed that in the year I937 the number of cases of syphilis with infections of less than one year's duration dealt with there for the first time (Appendix E, Table D) was 5,633 (M., 3,986 ; F., I,647) a reduction of 42 since the previous year and of 38. I per cent. since I93I. On the basis of the calculation that the number dealt with by the centres was at least 85 per cent. of the total coming under medical care, the number dealt with by treatment centres, other institutions and private practitioners would be approximately 6,600 or $\mathrm{I} \cdot 6$ per Io, ooo of the population. The further increase in the numbers of persons who have attended the centres for examination on their suspicion of having contracted a venereal disease and have been classed under 
the heading " Other than Venereal Disease" (Appendix $\mathrm{E}$, Table A) is evidence that, so far at any rate as males. are concerned, there is very little tendency in this. country to neglect seeking advice for syphilis presenting. any external manifestation.

Also, the tendency of males with early syphilis is to report earlier now than formerly. Thus the ratio of primary to secondary syphilis in males in the five years I933 to I937 was I to 0.47 . Although the figures on which a ratio on similar lines could be calculated are not available for all the centres prior to I932, such figures as are available suggest that in I92I for every male who first attended at a treatment centre whilst still in the primary stage, at least one other had delayed action until the outbreak of secondary signs.

Routine tests of the blood of prospective or actual mothers in certain ante-natal centres continue to support the evidence given above that the transmission of syphilis continues to decline.

Deaths of infants certified as due to syphilis were at the rate of 0.23 per I,000 live births as shown in Appendix E, Table F. Cases of congenital syphilis under one year of age that were dealt with at the centres are shown in Appendix E, Table E. They show a further reduction in spite of the fact that an increasingly careful watch is maintained every year for syphilis in infants. The numbers dealt with in 1937 were 37.8 per cent. fewer than in I93r. Substantial declines are also shown in the numbers of cases between one and I5 years of age, the combined figures for 1937 being 42.5 per cent. (500 cases) less than in I93I.

Deaths from general paralysis of the insane (Appendix $\mathrm{E}$, Table G) showed a further fall to 594 in the case of males but a slight rise to 253 in the case of females; the crude annual rates per million were 30 and I2 respectively. The corresponding rates in I9II were IOI and 23 and in 1920 they were $7 \mathrm{I}$ and $\mathrm{I2}$. As remarked in previous Reports the slightness of the decline in the female death rates since I920 is noteworthy, and shows that more effective measures should be taken to discover and treat syphilis in women.

Deaths from tabes dorsalis (locomotor ataxia) (Table G) fell to 473 in males, a crude rate of 24 per million, the lowest since I9II. The rate in females showed practically no change. 
Gonorrhoea.-The cases dealt with for the first time:in 1937. (Appendix E, Table C) were 29,250 males and 7,787 females, of which 27,630 males and 6,717 females had infections of less than one year's duration. The number of early cases represents a rate of 8.4 per I0,000: of the population in England and Wales. The figures show a slight increase over those in 1936, but this may be due to a larger proportion of the infected resorting to the treatment centres. Certainly the cases of gonorrhœa dealt with at the treatment centres in England and Wales represent a rate per 10,000 of the population which is much lower than those in the countries of Denmark and Sweden whose anti-venereal measures are very active and, so far as syphilis is concerned, most successful. Thus in r935 the cases of gonorrhœa reported in Sweden were at the rate of 17.9 per 10,000 of the population, and the corresponding rate in Denmark was $27^{\circ} 0$. The figures relating to gonorrhæa in females present (as in previous years) evidence that many cases must be going untreated.

Soft Chancre.-The numbers of cases of soft chancre were again low, less than $\mathrm{I}, 000$, and the ratio of males to females very high, 824 to 15. Most of the cases were reported by centres in ports. There is no evidence of any increase of disabilities resulting from infection with the virus of lymphogranuloma inguinale.

Failure to seek skilled advice for Venereal Disease and Premature Discontinuance of Attendance at the Centres.

Under this heading in the Chief Medical Officer's Report for 1936 readers were reminded that the reduction in the incidence of venereal diseases depends on the success of measures to $(a)$ dissuade people from extra-marital sexual intercourse and $(b)$ render the greatest possible proportion of the infected in the community noninfectious. The first of these essentials depends on enlightenment of the public. Success in rendering the greatest possible proportion of the infected non-infectious depends greatly on the numbers who seek treatment voluntarily, or are persuaded to do so ; the latter include persons suspected of having infected, or having been infected by, patients under treatment and those discovered to have venereal disease as a result of examination by officers in other branches of the Public Health Service, such as the Maternity and Child Welfare and 


\section{BRITISH JOURNAL OF VENEREAL DISEASES}

School Medical Services. The personal influence of medical officers, general practitioners, nurses and sympathetic trained social workers helps greatly to encourage victims of these diseases to obtain the skilled diagnosis and treatment available, whilst the British Social Hygiene Council has been untiring in its efforts to co-operate with Local Authorities in educational measures and to stimulate the interest of the public generally in the prevention and treatment of these dire diseases.

It is probable that the numbers being brought under treatment in the first place are too few, especially in the case of women with gonorrhœa and, to a less extent of those with syphilis. In the case of men with gonorrhœa, also, the numbers seeking treatment at the centres are much below those which one would expect from the ratios of gonorrhœa to syphilis in the armed forces, where concealment of venereal disease is a crime.

Naturally, it is necessary also that persons brought under treatment should continue so until there is a reasonable probability that they are no longer infectious. In regard to this requirement, the percentages of patients on the books of the treatment centres who discontinued attendance prematurely during the ten years ending 31st December, I937, were as follows :-

\begin{tabular}{|c|c|c|c|c|c|c|}
\hline & & \multicolumn{2}{|c|}{ Syphilis } & \multicolumn{2}{|c|}{ Gonorrhœa } \\
\hline & & & Males. & Females. & Males. & Females. \\
\hline I928 & . & . & $24 \cdot 7$ & $22 \cdot 8$ & $27 \cdot 5$ & $20 \cdot 4$ \\
\hline I93I & . & . & $24 \cdot 2$ & $22 \cdot 2$ & $29 \cdot 3$ & $2 \mathrm{I} \cdot 2$ \\
\hline I934 & - & - & $2 I \cdot 9$ & $20 \cdot 7$ & $23 \cdot 9$ & $22 \cdot 9$ \\
\hline I937 & . & . & $I 7 \cdot 4$ & $17 \cdot 9$ & $2 \mathrm{I} \cdot 8$ & $\mathrm{I} 8 \cdot 2$ \\
\hline
\end{tabular}

Of the syphilis cases constituting the above percentages in I937, about one fifth, and of the gonorrhœe cases from a third to a quarter had completed the prescribed treatment and were under tests of cure at the time they ceased attendance. Of the syphilis cases 77 per cent. males and 76 per cent. females had received more than one course of injections (usually of both arsphenamine compound and heavy metal) and probably a high proportion of them had become permanently non-contagious. It is necessary also to remember that of the cases of acquired syphilis which ceased to attend before completion of treatment over 50 per cent. of the males and 64 per cent. of the females had old infections when they first attended the centres and were for the most part already non-infectious from the sexual point of view. 
In spite of these and other mitigating factors, it must be admitted that premature discontinuance of attendance by patients is an important obstacle in the way of ridding the country of these diseases, and it is important periodically to review the measures designed to obviate the defects just discussed, namely, failure to seek treatment in the first place and premature discontinuance of treatment, in order to see if they could in any way be improved.

\section{Investigation of Treatment of Venereal Diseases in the Scandinavian Countries and in Holland.}

At various times the question has been raised if better progress would not be made in reducing the incidence of venereal diseases by compelling infected persons to undergo such treatment as would render them permanently non-contagious. Agitation for legislation to authorise measures of compulsion is stimulated by the reports from the treatment centres showing the percentage of the patients dealt with who discontinue treatment prematurely, and by local knowledge of persons known or suspected to be serious sources of infection who refuse to submit even to examination. Another powerful stimulus to a demand for compulsory measures is the knowledge that numbers of parents and guardians of children suffering from congenital syphilis neglect to take them for treatment, thereby seriously imperilling their future health.

Against the introduction of compulsory measures many objections have been raised, chiefly on the score of the possibility of their promoting concealment of venereal disease, their pressing more hardly on those who at least have sought treatment than on those who have concealed their diseases, the difficulty of tracing defaulting patients, and the possibility of the compulsory measures being used for purposes of blackmail. The general feeling on the matter was tested in the House of Commons on Igth April, 1928, when a Bill promoted by the Edinburgh Corporation to obtain powers to compel persons infected with venereal disease to undergo treatment was rejected on its second reading by 156 votes to 93. [Hansard, I928, 216, 446.]

Recently agitation for a reconsideration of the question has been roused by the publication, in 1936, of a report by 


\section{BRITISH JOURNAL OF VENEREAL DISEASES}

a New York Commission which visited this country and Denmark, Norway and Sweden in I935 to study the antivenereal measures in these countries. The report showed that in the Scandinavian countries mentioned a considerable measure of success had been achieved in reducing the incidence of syphilis. The British statistics, quoted in the U.S. report in a paragraph immediately succeeding that summarising the Scandinavian figures, contrasted unfavourably. In some quarters the apparently greater success of the Scandinavian measures was attributed to the fact that in Denmark, Norway and Sweden respectively there are laws under which persons suffering from any of the three principal venereal diseases can be compelled to undergo treatment.

Closer scrutiny showed that the figures relating to cases in England and Wales had unwittingly not been presented by the American reporters in quite a fair light. The numbers of old and new infections in this country were apparently compared with what purported to be only new infections in the Scandinavian countries. Apart from this the question required further investigation, and in 1937 the Minister of Health and the Secretary of State for Scotland appointed a mission to visit Denmark, Sweden and Norway, as well as Holland, to study the anti-venereal measures in each of those countries and their effect on the incidence of venereal diseases there. The choice of Holland was dictated by the fact that in that country, as in Great Britain, there are no compulsory measures, and it was felt that Holland might serve as a control on any inferences drawn from changes in the incidence of venereal diseases in the three countries which place more or less reliance on compulsory measures. Another reason for the choice of Holland as a control was that it appeared to be a country whose characteristics and social conditions are, in general, comparable with those of the three Scandinavian countries.

The mission consisted of Col. L. W. Harrison and Mr. Dudley C. L. Ward of the Ministry of Health, Dr. T. Ferguson of the Department of Health for Scotland and Dr. Margaret Rorke of the Royal Free Hospital, London. Its report which was published during the present year discusses in the case of each country geographical and social factors as might have a bearing on the spread of venereal diseases, the laws, if any, under which anti- 


\section{CIVILIAN ANTI-VENEREAL WORK}

venereal measures are undertaken, the working of those measures in actual practice and the figures relating to the incidence of syphillis and gonorrhœa over a number of years.* The information afforded in the section relating to each country is very detailed and should make the report useful for reference purposes for a number of years.

The conclusions of the report are as follows :-

“ (I) Our enquiries in Denmark and Sweden, the two countries in which laws specially directed to combating venereal diseases are in operation, led us to the conclusion that the measures are regarded as beneficial and receive the co-operation of the public. We could find no evidence that the operation of the law has led to concealment of disease to any appreciable extent or imposed undue hardship on the people. In our view the smooth running of the arrangements is largely attributable to the national characteristics and social outlook of the people and to the influential position of the medical profession in these countries.

" In Norway, though there is no special anti-venereal law, the authorities have power to secure the compulsory isolation of patients with venereal diseases, but these powers do not appear to be exercised very strictly. We are unable to express an opinion on the probable reaction of the people to a more rigid enforcement of the law in this respect.

" (2) As a result of our investigation of the anti-venereal measures in force in Denmark, Sweden, Norway and Holland, and from our knowledge of the arrangements in operation in Great Britain, we conclude that in each of these five countries the authorities have been able to secure a sufficient degree of cooperation by infected persons to achieve a substantial measure of success in reducing the incidence of syphilis. On the other hand, none of these countries has been outstandingly successful in effecting a reduction in the incidence of gonorrhœa.

" (3) Considering that in the countries employing compulsory treatment and in those which rely on a voluntary system the degree of success in reducing the incidence of syphilis and of relative failure in gonorrhœa are broadly similar, compulsory treatment does not seem to us to be a major factor influencing the results of the anti-venereal measures in the countries where it is employed."

Outstanding features of the arrangements in Denmark and Sweden appeared to be the smoothness with which they worked, the confidence of the patients in their medical attendants and consequently their natural willingness to obey instructions. In Holland the sympathetic social service appeared to be a factor of great importance in

* " Report on Anti-Venereal Measures in certain Scandinavian Countries and Holland," 1938, Reps. on P.H. and Med. Sub. No. 83. H.M. Stationery Office. 


\section{BRITISH JOURNAL OF VENEREAL DISEASES}

maintaining attendances and in tracing sources of infection.

\section{Laboratory assistance in the Diagnosis of Venereal Diseases.}

The numbers of tests of specimens examined under the Venereal Diseases Scheme in the approved laboratories and the treatment centres is shown in Appendix E, Table $\mathrm{H}$; the total was 816,033 , of which 85,398 were microscopical examinations carried out by clinicians in the treatment centres.

Of the 730,635 tests carried out in approved laboratories, 12,090 were tests of the spinal fluid that were additional to the Wassermann. Such tests have not been shown in the corresponding table in previous reports and were first required to be shown in the laboratory returns for 1936 .

It is noteworthy that the serum tests for syphilis carried out for practitioners and institutions other than treatment centres have increased very greatly in the past few years; the increase since I934 having been over 43 per cent. There are good reasons for the view that this increase is not due to any increase of fresh infections. especially so as almost an of it is accounted for by specimens from institutions which would send such cases to the treatment centres. and the conclusion is that it is explained by the growing tendency to employ serum tests for syphilis in routine medical examinations.

Table $\mathrm{H}$ shows also a remarkable increase in the numbers of tests of spinal fluid, especially for practitioners and institutions other than venereal diseases treatment centres.

Flocculation tests carried out in addition to the Wassermann test again showed a great increase, and the same applies to gonococcal complement fixation tests.

\section{Conferences.}

Dr. A. E. Quine, a Medical Officer of the Ministry of Health, attended the General Assembly of the Union Internationale contre le Péril Vénérien at Cologne in July-August, I937, when the principal matters discussed were (a) The organisation of treatment of venereal diseases in rural areas, and $(b)$ Co-operation between the countries bordering on the Rhine to establish a coordinated system of treatment centres for Rhine boatmen.

\section{Venereal Diseases in Wales.}

The number of treatment centres in Wales remains the same, namely, 14. Compared with I936, the number of new cases of gonorrhœea increased from 2,439 to 2,537, but new cases of syphilis declined from 728 to 709 . 


\section{CIVILIAN ANTI-VENEREAL WORK}

\section{APPENDIX E}

England and Wales: Tables relating to Venereal Diseases.

TABLE A

\begin{tabular}{|c|c|c|c|c|c|c|c|c|}
\hline \multirow{2}{*}{ Year. } & \multicolumn{6}{|c|}{$\begin{array}{l}\text { Number of Cases in all Stages, dealt with for the first time at the } \\
\text { Treatment Centres.* }\end{array}$} & \multirow{2}{*}{$\begin{array}{c}\text { Total } \\
\text { Number of } \\
\text { Attendances. }\end{array}$} & \multirow{2}{*}{$\begin{array}{l}\text { Number of } \\
\text { Treatment } \\
\text { Centres at } \\
\text { 'end of Year }\end{array}$} \\
\hline & Syphilis. & $\begin{array}{c}\text { Soft } \\
\text { Chancre. }\end{array}$ & Gonorrhœa. & $\begin{array}{l}\text { Total } \\
\text { V.D. }\end{array}$ & $\begin{array}{l}\text { Other } \\
\text { than } \\
\text { V.D. }\end{array}$ & Total. & & \\
\hline 1917 & - & - & - & - & - & 29,036 & 204,692 & I 13 \\
\hline 1918 & 26,912 & 806 & I 7,635 & 45,353 & 6,622 & 51,975 & 488,137 & 134 \\
\hline I919 & 42, I 34 & 2,164 & 38,499 & 82,797 & I 5,447 & 98,244 & $\mathrm{I}, 002,79 \mathrm{I}$ & 160 \\
\hline I920 & 42,805 & 2,442 & 40,284 & $85,53 \mathrm{I}$ & I 9,654 & $10_{5}, 185$ & $\mathrm{I}, 488,5^{\mathrm{I}} 4$ & 190 \\
\hline I921 & 32,733 & 1,654 & 32,433 & 66,820 & I 7,459 & 84,279 & $1,612,592$ & 194 \\
\hline I922 & 25,762 & 1,108 & 29,477 & 56,347 & I6,988 & 73,335 & $1,560,568$ & I9I \\
\hline I923 & 23,927 & I, I IO & 30,908 & 55,945 & I 7,668 & 73,613 & $\mathrm{I}, 605,6 \mathrm{I}_{7}$ & 192 \\
\hline 1924 & 22,010 & 1,098 & 31,272 & $54,3^{80}$ & I8,842 & 73,222 & $\mathrm{I}, 645,4^{\mathrm{I}} 5$ & 193 \\
\hline r925 & $22,5^{88}$ & I, 106 & $33,4^{6} 3$ & 57, I 57 & 21,053 & 78,2 Io & $\mathrm{I}, 7 \mathrm{I} 9, \mathrm{I}_{48}$ & 193 \\
\hline 1926 & $22,55^{\circ}$ & $\mathrm{I}, \mathrm{I} 5^{\circ}$ & 35,052 & $58,75^{2}$ & 22,754 & 81,506 & $2,008,063$ & I90 \\
\hline 1927 & 23,395 & 1,063 & $3^{8,242}$ & 62,700 & 25,436 & 88, I 36 & $2,179,707$ & I 86 \\
\hline 1928 & 22,761 & 1,138 & 42,032 & 65,931 & 28,029 & 93,960 & $2,422,749$ & I 88 \\
\hline r929 & 22,019 & I, 298 & $44, \mathrm{I} 66$ & $67,4^{8} 3$ & 27,980 & 95,463 & $2,604,217$ & I 88 \\
\hline I930 & 23,120 & 1,324 & 45, OOI & 69,445 & 31,104 & IOO, 549 & $2,817,195$ & I90 \\
\hline I93I & 22,934 & 1,163 & 42,460 & 66,557 & $3 \mathrm{I}, 82 \mathrm{I}$ & $98,37^{8}$ & $2,992,76$ I & I89 \\
\hline I932 & 22,215 & $95^{2}$ & $4 I, 25 I$ & 64,418 & 32,997 & 97,4 I 5 & $3,109,174$ & I 88 \\
\hline I933 & 21,525 & 926 & 43,226 & 65,677 & $32,7^{6} 7$ & 98,444 & $3,252,323$ & I 86 \\
\hline 1934 & 20,692 & 960 & 43,391 & 65,043 & 36,3 I I & IOI, 354 & $3,407,000$ & I84 \\
\hline I935 & I9,335 & I, II 2 & $41,33^{2}$ & 61,779 & 36,230 & 98,009 & $3,398,678$ & 185 \\
\hline 1936 & I8,609 & 1,000 & 42,230 & 61,839 & 36,719 & $98,55^{8}$ & $3,360,328$ & 186 \\
\hline I937 & I9, I85 & $94 I$ & 43,802 & 63,928 & 38,591 & 102,519 & $3,34^{2}, 57 \mathrm{I}$ & I86 \\
\hline
\end{tabular}

* Includes cases transferred from centre to centre and those that returned after being struck off the books in previous years.

TABLE B.-Attendances per Current Case.

\begin{tabular}{|c|c|c|c|c|}
\hline \multirow{2}{*}{ Year. } & \multicolumn{2}{|c|}{ Syphilis. } & \multicolumn{2}{|c|}{ Gonorrhœa. } \\
\hline & Males. & Females. & Males. & Females. \\
\hline 1923 & $6 \cdot 8$ & $7 \cdot 3$ & $15 \cdot 7$ & I 5.5 \\
\hline 1928 & $9 \cdot I$ & $9 \cdot 3$ & $24^{\circ} \mathrm{O}$ & I8.1 \\
\hline 1929 & 9.5 & $9 \cdot 2$ & 24.5 & I $7 \cdot 7$ \\
\hline 1930 & $9 \cdot 8$ & $9 \cdot 7$ & $26 \cdot 5$ & $18 \cdot 0$ \\
\hline I93I & 10.7 & II.O & $29^{\circ} 0$ & $20 \cdot 4$ \\
\hline 1932 & I. $\cdot 9$ & $12 \cdot 0$ & $3 I \cdot 7$ & $21 \cdot 4$ \\
\hline 1933 & $12 \cdot 2$ & $12 \cdot 5$ & $32 \cdot 2$ & $23 \cdot 5$ \\
\hline 1934 & $12 \cdot 4$ & I3. I & $34^{\circ} \circ$ & $25 \cdot 9$ \\
\hline r935 & $12 \cdot 9$ & r 3.6 & $34 \cdot 9$ & $26 \cdot 5$ \\
\hline r936 & $12 \cdot 9$ & I $3 \cdot 8$ & $34 \cdot 3$ & $27 \cdot 4$ \\
\hline I937 & $12 \cdot 7$ & I $3 \cdot 4$ & $33^{\circ} 0$ & $27^{\circ} 0$ \\
\hline
\end{tabular}


BRITISH JOURNAL OF VENEREAL DISEASES

TABLE C.-Number of Cases (in all Stages) dealt with for the first time at any Centre.*

\begin{tabular}{|c|c|c|c|c|c|c|c|}
\hline \multicolumn{4}{|c|}{ Year. } & Syphilis. & Soft Chancre. & Gonorrhœea. & Total V.D. \\
\hline$\underset{S}{S}$ & $\begin{array}{l}1925 \\
1926 \\
1927 \\
1928 \\
1929 \\
1930 \\
1931 \\
1932 \\
1933 \\
1934 \\
1935 \\
1936 \\
1937 \\
\end{array}$ & $\begin{array}{l}\dot{.} \\
\dot{.} \\
\dot{.} \\
\dot{.} \\
\dot{.} \\
\dot{.} \\
. \\
. \\
. \\
.\end{array}$ & $\begin{array}{l}\dot{.} \\
\dot{.} \\
\dot{.} \\
\dot{.} \\
\dot{.} \\
\dot{.} \\
\dot{.} \\
\dot{.} \\
.\end{array}$ & $\begin{array}{r}\text { I I }, 782 \\
\text { I } 2,1 \text { I } 8 \\
\text { I } 2,393 \\
\text { I } 2,051 \\
\text { I I, } 538 \\
\text { I I } 967 \\
\text { I I } 285 \\
\text { I I,032 } \\
\text { I0,738 } \\
9,615 \\
8,596 \\
8,224 \\
8,069\end{array}$ & $\begin{array}{r}\mathrm{I}, 048 \\
\mathrm{I}, 070 \\
986 \\
\mathrm{I}, 053 \\
\mathrm{I}, 202 \\
\mathrm{I}, 244 \\
\mathrm{I}, 042 \\
845 \\
826 \\
876 \\
\mathrm{I}, 0 \mathrm{I} \text { I } \\
880 \\
824\end{array}$ & $\begin{array}{l}24,398 \\
25,535 \\
28,195 \\
30,425 \\
31,810 \\
32,217 \\
29,310 \\
28,179 \\
29,169 \\
28,787 \\
27,506 \\
28,137 \\
29,250\end{array}$ & $\begin{array}{l}37,228 \\
38,723 \\
41,574 \\
43,529 \\
44,550 \\
45,428 \\
41,637 \\
40,056 \\
40,733 \\
39,278 \\
37,113 \\
37,241 \\
38,143\end{array}$ \\
\hline 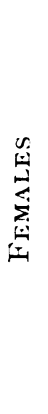 & $\begin{array}{l}1925 \\
1926 \\
1927 \\
1928 \\
1929 \\
1930 \\
1931 \\
1932 \\
1933 \\
1934 \\
1935 \\
1936 \\
1937\end{array}$ & 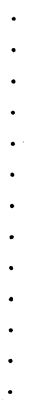 & $\begin{array}{l}\dot{b} \\
\dot{v} \\
\dot{v}\end{array}$ & $\begin{array}{l}7,385 \\
7,133 \\
7,553 \\
7,090 \\
6,586 \\
6,916 \\
6,827 \\
6,461 \\
6,029 \\
5,838 \\
5,565 \\
5,128 \\
5,165\end{array}$ & $\begin{array}{l}27 \\
21 \\
20 \\
28 \\
22 \\
17 \\
20 \\
29 \\
22 \\
10 \\
16 \\
29 \\
15\end{array}$ & $\begin{array}{l}6,120 \\
6,4 \text { I } 6 \\
6,809 \\
7,810 \\
7,798 \\
7,939 \\
7,697 \\
7,677 \\
8,583 \\
8,199 \\
7,732 \\
7,715 \\
7,787\end{array}$ & 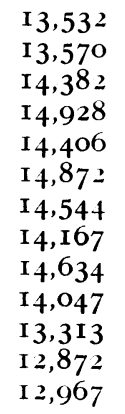 \\
\hline
\end{tabular}

*Excludes cases transferred from centre to centre and those that returned with the same infections after being struck off the books in previous years.

TABLE D.-Cases of Acquired Syphilis in Table C, with Infections of less than One Year.

\begin{tabular}{|c|c|c|c|c|c|c|c|}
\hline & \multirow{2}{*}{ Year. } & & \multicolumn{2}{|c|}{ Number. } & \multicolumn{2}{|c|}{ Per cent. of Table C Cases. } & \multirow{2}{*}{$\begin{array}{c}\text { Rate per } \\
\text { Io,ooo } \\
\text { Population. }\end{array}$} \\
\hline & & & M. & F. & M. & F. & \\
\hline I93I & . & . & 6,421 & 2,683 & $56 \cdot 9$ & $39 \cdot 3$ & $2 \cdot 28$ \\
\hline 1932 & . & . & 6,196 & 2,532 & $56 \cdot 2$ & $39 \cdot 2$ & $2 \cdot 17$ \\
\hline 1933 & - & - & 5,949 & $2, I_{4} I$ & $55 \cdot 4$ & $35 \cdot 5$ & $2 \cdot 0 I$ \\
\hline I934 & . & . & 4,888 & 2,030 & $50 \cdot 8$ & $34 \cdot 8$ & $\mathrm{I} \cdot 7 \mathrm{I}$ \\
\hline I935 & - & - & 4,226 & $\mathrm{I}, 745$ & $49 \cdot 2$ & $3 I \cdot 4$ & $I \cdot 47$ \\
\hline I936 & $\cdot$ & $\cdot$ & 4,033 & 1,642 & $49^{\circ} \mathrm{O}$ & $32 \cdot 0$ & $I \cdot 40$ \\
\hline r937 & · & $\cdot$ & 3,986 & 1,647 & $49 \cdot 4$ & $31 \cdot 9$ & $\mathrm{I} \cdot 37$ \\
\hline
\end{tabular}




\section{CIVILIAN ANTI-VENEREAL WORK}

TABLE E.-Cases of Congenital Syphilis dealt with for the first time at the Treatment Centres.

\begin{tabular}{|c|c|c|c|c|c|}
\hline Year. & Under I year. & $\begin{array}{l}\mathrm{I} \text { and under } \\
5 \text { years. }\end{array}$ & $\begin{array}{l}5 \text { and under } \\
\text { I5 years. }\end{array}$ & $\begin{array}{l}\text { I5 years and } \\
\text { over. }\end{array}$ & Totals. \\
\hline I93I & 339 & 204 & 974 & 922 & 2,439 \\
\hline I932 & 302 & 180 & 857 & 805 & $2, I_{44}$ \\
\hline I933 & 305 & I 57 & 774 & 780 & 2,016 \\
\hline I934 & 296 & I65 & 708 & 839 & 2,008 \\
\hline I935 & $25 \mathrm{I}$ & 165 & 671 & 944 & 2,031 \\
\hline I936 & $24 I$ & 132 & 600 & 935 & $\mathrm{I}, 908$ \\
\hline I937 & 2 II & I 44 & .534 & 940 & 1,829 \\
\hline
\end{tabular}

TABLE F.-Death Rates, per r,ooo Live Births, of Infants under One Year certified as due to Syphilis.-Information extracted from the Registrar-General's Statistical Reviews.

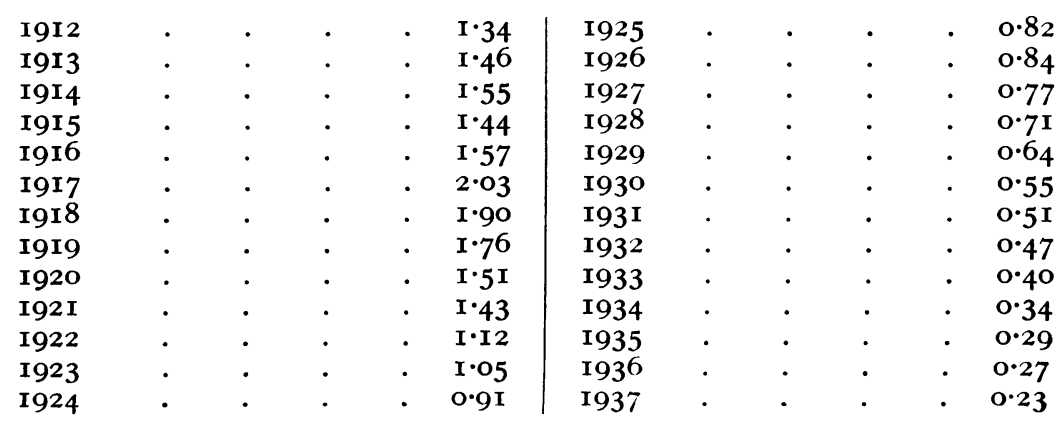


Table G.-General Paralysis of the Insane and TABES Dorsalis

Deaths and Crude Annual Death Rates per million living.-Information extracted from the Registrar-General's Statistical Reviews.

\begin{tabular}{|c|c|c|c|c|c|c|c|c|}
\hline \multirow{3}{*}{ Year. } & \multicolumn{4}{|c|}{ General Paralysis of the Insane. } & \multicolumn{4}{|c|}{ Tabes Dorsalis. } \\
\hline & \multicolumn{2}{|c|}{ Males. } & \multicolumn{2}{|c|}{ Females. } & \multicolumn{2}{|c|}{ Males. } & \multicolumn{2}{|c|}{ Females. } \\
\hline & Actuals. & $\begin{array}{l}\text { Crude } \\
\text { Rate. }\end{array}$ & Actuals. & $\begin{array}{l}\text { Crude } \\
\text { Rate. }\end{array}$ & Actuals. & $\begin{array}{l}\text { Crude } \\
\text { Rate. }\end{array}$ & Actuals. & $\begin{array}{l}\text { Crude } \\
\text { Rate. }\end{array}$ \\
\hline I9II & $\mathbf{1}, 763$ & IOI & 438 & 23 & 530 & 30 & $\mathrm{IO}_{5}$ & 6 \\
\hline 1914 & 1,831 & 102 & 434 & 23 & 600 & 34 & 120 & 6 \\
\hline I9I7 & $I, 940$ & I 26 & $4^{25}$ & 22 & $64 I$ & 45 & I I 6 & 6 \\
\hline I920 & $I, 270$ & $7 I$ & 234 & 12 & 522 & 29 & 87 & 4 \\
\hline 1926 & $\mathrm{I}, \mathbf{I} 6 \mathrm{I}$ & 62 & 277 & I4 & 630 & 34 & I I 7 & $\dot{6}$ \\
\hline I93I & 945 & 49 & 259 & 12 & 557 & 29 & I I 4 & 5 \\
\hline 1932 & 864 & 45 & 236 & I I & 634 & 33 & I 44 & 7 \\
\hline 1933 & $77 I$ & 40 & 239 & I I & 592 & $3 I$ & I 4 I & 7 \\
\hline 1934 & 788 & $4 I$ & 224 & I I & 496 & 26 & 107 & 5 \\
\hline 1935 & 725 & 37 & 240 & I I & 553 & 28 & I 18 & 6 \\
\hline 1936 & 652 & 33 & 232 & I I & 496 & 25 & IO4 & 5 \\
\hline I 937 & 594 & 30 & 253 & 12 & 473 & 24 & 116 & 5 \\
\hline
\end{tabular}




\section{CIVILIAN ANTI-VENEREAL WORK}

\section{TABLE H. - Examinations of Specimens. - (a) In Approved Laboratories, (b) In V.D. Treatment Centres.}

\begin{tabular}{|c|c|c|c|c|c|c|c|c|}
\hline & \multicolumn{4}{|c|}{ For V.D. Treatment Centres. } & \multicolumn{4}{|c|}{$\begin{array}{l}\text { For Practitioners and Institutions other } \\
\text { than V.D. Treatment Centres. }\end{array}$} \\
\hline & r934. & 1935. & 1936. & 1937. & 1934. & 1935. & 1936. & 1937. \\
\hline $\begin{array}{r}\text { Microscopical- } \\
\text { For S. pallida } \\
\qquad(a) \\
(b)\end{array}$ & $\begin{array}{l}1,549 \\
4,078 \\
\end{array}$ & $\begin{array}{l}1,815 \\
4,751 \\
\end{array}$ & $\begin{array}{l}1,912 \\
4,881 \\
\end{array}$ & $\begin{array}{l}I, 5^{8} \mathrm{I} \\
4,4^{84} \\
\end{array}$ & $\mathrm{~L}^{193}$ & $\mathrm{I}^{\mathrm{I}} 35$ & $\mathrm{I}^{\mathrm{I} 99}$ & $-^{231}$ \\
\hline Totals & 5,627 & 6,566 & 6,793 & 6,065 & I93 & I 35 & 199 & $23 I$ \\
\hline $\begin{array}{r}\text { For gonococci } \\
(a) \\
(b)\end{array}$ & $\begin{array}{r}165,896 \\
67,471\end{array}$ & $\begin{array}{r}\mathbf{6} 66,978 \\
75,219\end{array}$ & \begin{tabular}{|r|}
167,953 \\
69,1 \\
\end{tabular} & $\begin{array}{r}\mathrm{I} 7 \mathrm{I}, 363 \\
80,9 \mathrm{I} 4\end{array}$ & 27,033 & 26,423 & 21,910 & 24,132 \\
\hline Totals & 233,367 & 242,197 & 237,072 & 252,277 & 27,033 & 26,423 & 21,910 & 24,132 \\
\hline $\begin{array}{c}\text { Serum tests }(a) \\
\text { For syphilis- } \\
* \text { W a s ser- } \\
\text { mann } . \\
\text { Others } \\
\text { For gonorrhœa } \\
\end{array}$ & $\begin{array}{r}134,324 \\
39,830 \\
36,386 \\
\end{array}$ & $\begin{array}{r}134,072 \\
44,459 \\
42,621 \\
\end{array}$ & $\begin{array}{r}133,534 \\
47,410 \\
43,815 \\
\end{array}$ & $\begin{array}{r}\mathrm{I} 36,603 \\
6 \mathrm{r}, 400 \\
5 \mathrm{I}, 324 \\
\end{array}$ & $\begin{array}{r}103,983 \\
19,211 \\
4,004 \\
\end{array}$ & $\begin{array}{r}\mathrm{I} 12,520 \\
\mathrm{I} 8,267 \\
6,136 \\
\end{array}$ & $\begin{array}{r}119,926 \\
30,886 \\
7,221 \\
\end{array}$ & $\begin{array}{r}\text { I } 36,165 \\
40,096 \\
7,769 \\
\end{array}$ \\
\hline $\begin{array}{c}\text { Tests of cerebro- } \\
\text { spinal fluid }(a) \\
+ \text { Was ser- } \\
\text { mann } \\
\text { Others }\end{array}$ & 1,288 & $I^{1,5} 3$ & $\begin{array}{l}1,324 \\
3,382 \\
\end{array}$ & $\begin{array}{l}2,132 \\
3,931 \\
\end{array}$ & 4,400 &,$+ 73^{6}$ & $\begin{array}{l}6,035 \\
6,246 \\
\end{array}$ & $\begin{array}{l}7,760 \\
8,159 \\
\end{array}$ \\
\hline Cultures $(a)$ & 51,926 & $6 \mathrm{I}, 4 \mathrm{OI}$ & 68,778 & 70,695 & 5,122 & 4,598 & $\mathrm{I}, 45^{\circ}$ & $I, 488$ \\
\hline $\begin{array}{l}\text { Others not clas- } \\
\text { sified above }(a)\end{array}$ & 8,234 & 5,703 & 8,885 & 5,233 & 797 & I, 059 & 316 & 573 \\
\hline $\begin{array}{l}\text { Totals excluding } \\
\text { C.S.F. "others" }\end{array}$ & 510,982 & 538,532 & $547,6 \mathrm{I} \mathrm{I}$ & $585,729 \mid$ & 164,743 & 173,874 & 187,943 & $218,2 I_{4}$ \\
\hline $\begin{array}{l}\text { Totals including } \\
\text { C.S.F. "others" }\end{array}$ & - & - & 550,993 & 589,660 & - & - & $\mathrm{r} 94, \mathrm{r} 89$ & 226,373 \\
\hline
\end{tabular}

* Kahn, Meinicke, Müller-Ballungs, Sigma, Vernes, \&c., always applied in addition to the Wassermann.

† Cell count, globulin, colloidal, protein, sugar, Kahn, Sigma, \&c., practically always in addition to the Wassermann. Figures not available prior to 1936.

Tables I to 3, which follow, were not part of the above report; they refer to incidence of venereal diseases in the Navy, Army and Air Force, as mentioned in the foreword. 
BRITISH JOURNAL OF VENEREAL DISEASES

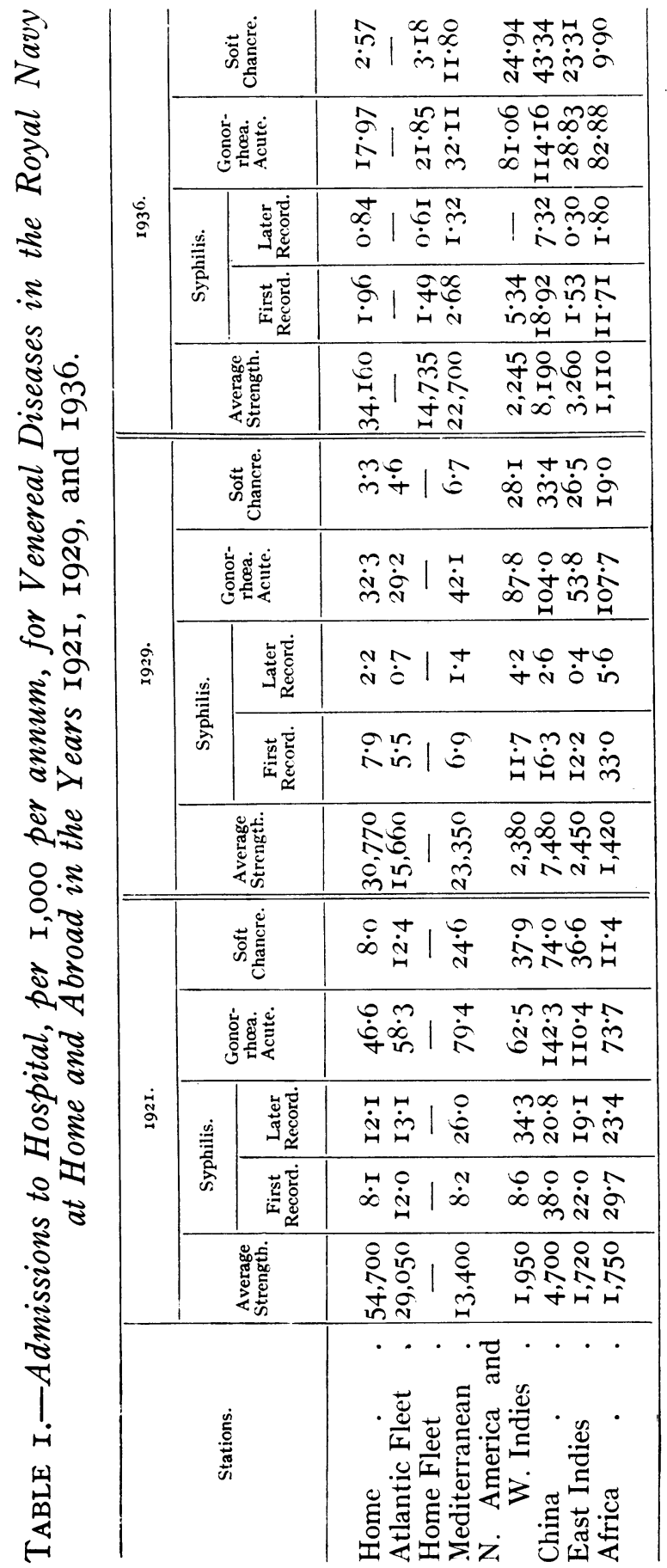


CIVILIAN ANTI-VENEREAL WORK

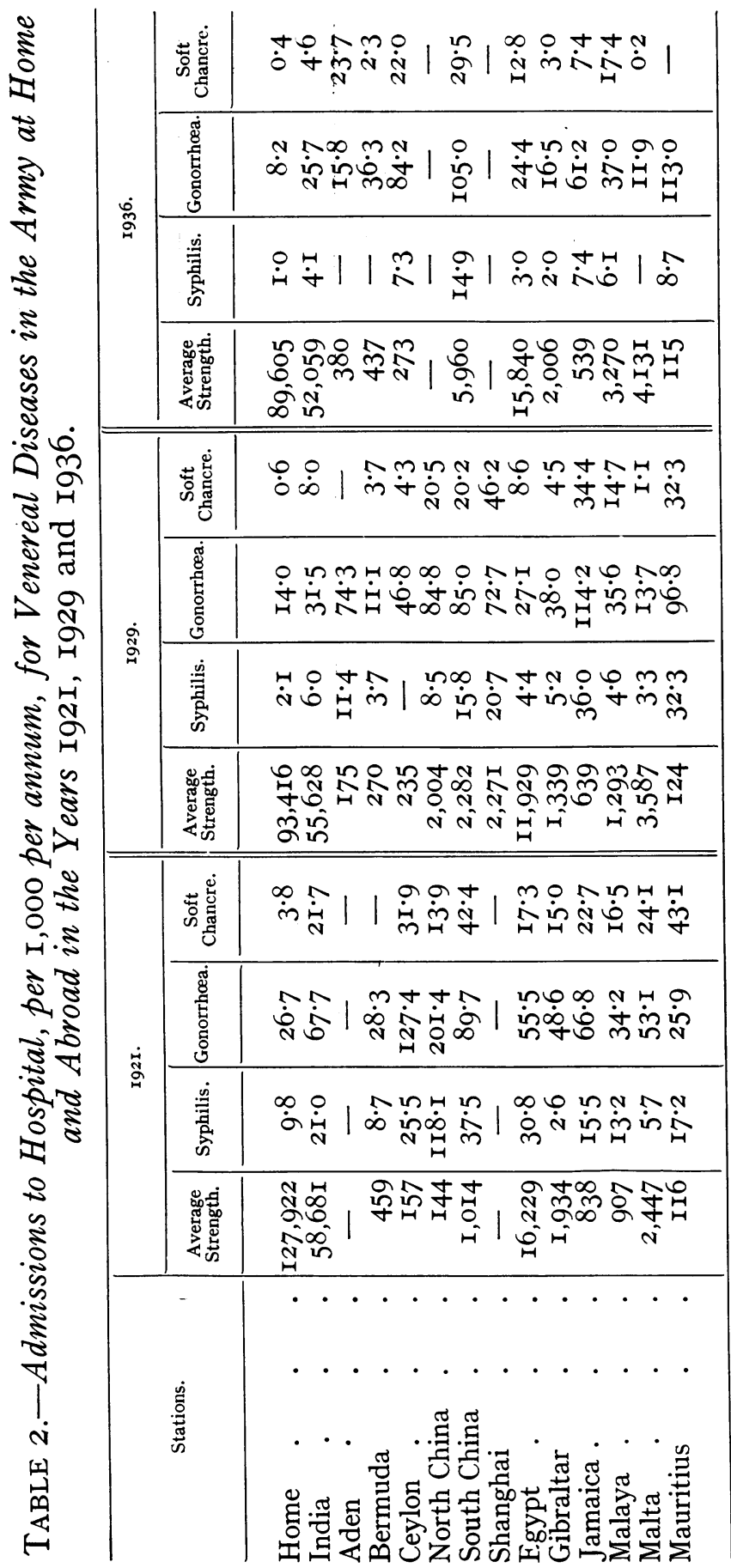


BRITISH JOURNAL OF VENEREAL DISEASES

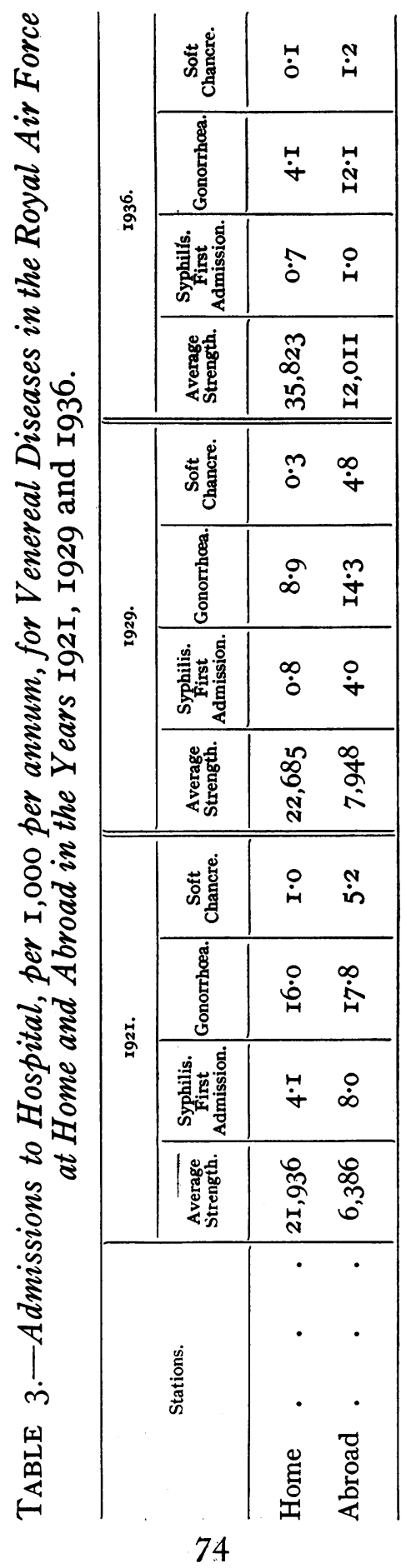

